\title{
BOLYGÓDUGATTYÚS PNEUMATIKUS MOTOR
}

\section{PNEUMATIC MOTOR WITH PLANETARY PISTON}

\author{
Kakucs András ${ }^{1}$, Papp István ${ }^{2}$, Forgó Zoltán ${ }^{3}$, Tolvaly Roşca Ferenc ${ }^{4}$ \\ Sapientia-EMTE, Müszaki és Humántudományok kar, Gépészmérnöki tanszék, \\ Cím: 540485, RO, Marosvásárhely, Segesvári u. 1/c, \\ ${ }^{1}$ kakucs2@ms.sapientia.ro \\ 2pappistvan@ms.sapientia.ro \\ ${ }^{3}$ zforgo@ms.sapientia.ro \\ ${ }^{4}$ tferi@ms.sapientia.ro
}

\begin{abstract}
In our project, which was supported by the Institute for Scientific Research of the Sapientia Foundation, we have developed a Wankel-engine-like (fig. 1) planetary-piston pneumatic motor. The essence of the innovation is that the "fuel" of the engine is compressed air and it has more simultaneously active chambers. The number of these chambers can be increased, leading to a curved polygonal contour of the piston moving inside a stator with complex geometry. This machine is a volumetric one (i.e. not a turbine) and its efficiency can be increased by letting the compressed air to expand in the active chamber.
\end{abstract}

Keywords: planetary piston, pneumatics

\section{Összefoglalás}

A KPI által támogatott kutatási pályázatunk keretében egy bolygódugattyús pneumatikus motort fejlesztünk. E motor felépítésében a Wankel-motorra (1. ábra) emlékeztet, amely egy belső égésü motor. Az újítás abban áll, hogy a motor sürített levegővel fog müködni, és nem egy, hanem több egyidejűleg aktív munkatere van. A munkaterek száma megnövelhető, ennek következtében a bolygódugattyú nem egy görbült oldalú háromszög, hanem egy sokszög profilú elem lesz, amely egy bonyolultabb geometriájú állórészben fog bolygómozgást végezni. Ez egy térfogat-kiszorítású gép (tehát nem turbina), amelynek a gazdaságos müködtetéséhez a levegőt kiterjeszkedni hagyjuk az aktív munkatérben.

Kulcsszavak: bolygódugattyús motor, pneumatika

\section{A motor geometriája}

Kiindulási alapként tekintsük a Wankelmotort. Legfontosabb alkatrészei (2. ábra, [1], [2]):

- az állórész, amelynek fedőlapjaiban vannak a bebocsátó és kibocsátó nyílások (ugyanis e motornak nincsenek szelepei), ez tartja az álló, külső fogazású fogaskereket és a tengely csapágyait, ide vannak becsavarozva a gyújtógyertyák, a járataiban keringő folyadék pedig a motor hütését oldja meg;

- a forgórész, amelyben fellelhetjük a belső fogazású bolygókereket és a tömítés elemeit; valamint 
- a tengely, amely excenteres megoldású a kisméretü excentrikusság miatt (nem lehet forgattyús mechanizmust építeni).

A forgórész egy görbült oldalú háromszög, amely bolygómozgást végez az állórészben. A forgórész körbe kell mozogjon az állórészben, anélkül hogy megszorulna, ez a mozgás pedig egy összetett síkmozgás.

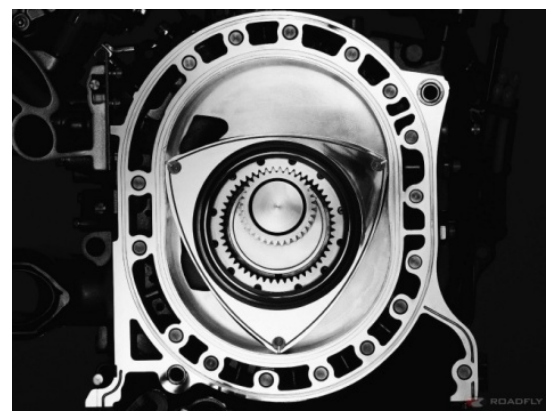

1. ábra. Wankel-motor (forrás: internet)

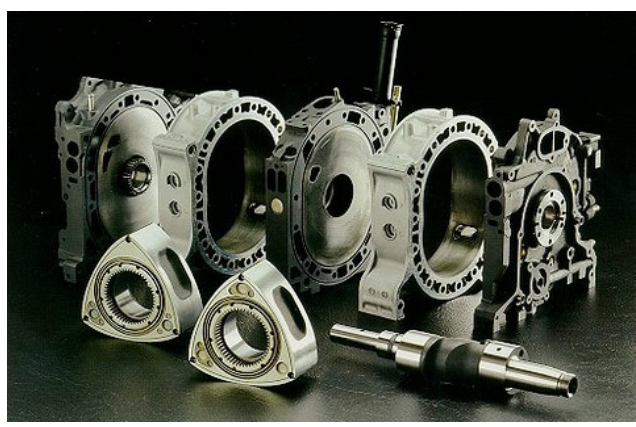

2. ábra. Kétdugattyús Wankel-motor fontosabb alkatrészi (forrás: internet)

\subsection{Az állórész}

Az állórész üregének körvonalát úgy lehet megszerkeszteni, hogy az álló fogaskerék gördülőkörén legördítjük a belsőfogazású bolygókerék gördülőkörét, ez utóbbi gördülőkörhöz pedig hozzárendeljük a bolygódugattyú éleinek megfelelö végpontokat. E pontok rajzolják ki a keresett körvonalat, amely egy epitrochoid.

$\mathrm{Az}$ epitrochoid az a görbe, amelyet egy körön csúszásmentesen legördülő második körrel együtt forgó pont ír le, a 3. ábra szerint.

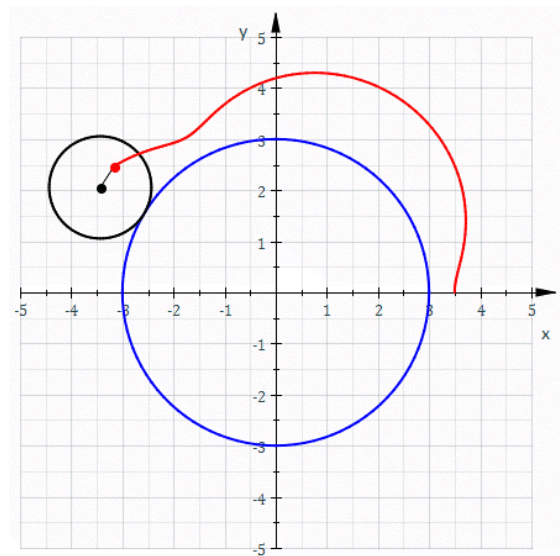

3. ábra. Epitrochoid (forrás: Wikipédia)

Ennek parametrikus egyenletei:

$$
\begin{array}{r}
x(\theta)=(R+r) \cdot \cos (\theta)-d \cdot \cos \left(\theta \cdot \frac{R+r}{r}\right), \\
y(\theta)=(R+r) \cdot \sin (\theta)-d \cdot \sin \left(\theta \cdot \frac{R+r}{r}\right),
\end{array}
$$

ahol $R$ az álló, $r$ pedig a legördülő kör sugara, $d$ az epitrochoidot megrajzoló pont távolsága a legördülő kör középpontjától, $\theta$ pedig a paraméter (ez tulajdonképpen a két kör érintkezési pontjának központi szöge az ábrázolt koordináta-rendszer $x$ tengelyétől mérve).

Céljainknak csak olyan epitrochoid görbék felelnek meg, amelyek önmagukban záródnak (egyébként a dugattyú éle eltávolodna az állórész belső felületétől, és a munkaterek egybenyílnának), tehát $R$ és $r$ aránya egész szám kell legyen (a Wankelmotor esetében ez az arány 2). A $d$ távolság az epitrochoid legnagyobb és legkisebb sugarának viszonyát adja meg, tehát a Wankel-motor esetében a rotor ,„8"-ra emlékeztető formáját. 
Egy egyszerü kis programot írtunk, kívánt epitrochoidot, néhány példa a követamely az (1) képlet alapján megrajzolja a kező két táblázatban látható.

1. táblázat. Különbözö paraméterezésü kettős hurkú epitrochoidok

$\frac{R}{r}=2, \quad \frac{r}{d}=\infty(d=0)$


2. táblázat. Epitrochoidok, a hurkok száma 1, 2, 3 és 4

\begin{tabular}{|l|l|}
\hline$\frac{R}{r}=1, \quad \frac{r}{d}=2$ & $\frac{R}{r}=2, \quad \frac{r}{d}=3$ \\
\hline$\frac{R}{r}=3, \frac{r}{d}=4$ & $\frac{R}{r}=4, \frac{r}{d}=5$ \\
\hline
\end{tabular}

A táblázatok alapján levonható egy pár következtetés a $d$ paramétert illetően:

- minél kisebb az értéke, annál közelebb áll az epitrochoid egy $R^{\prime}=R+r$ sugarú körhöz;

- ha $d<r$, akkor az epitrochoid sima;

- ha $d=r$, akkor az epitrochoid csúcsban találkozó ívekből fog állni (ez egy epiciklois lesz);

- ha $d>r$, akkor az epitrochoid hurkolt lesz.

Nyilvánvaló tehát, hogy:

- a motorunk esetében $\frac{R}{r}=(n-1)$ egész szám kell legyen, ahol $n$ a dugattyú éleinek száma;

- az élek tömítésének szempontjából az epitrochoid minél simább kell legyen $(d<r)$,
- azonban $d$-t nem vehetjük tetszőlegesen kicsinek, ugyanis a munkatér térfogatának a motor egy ciklusa alatt egy $V_{\min }$ és $V_{\max }$ érték között kell változnia, ami a belső égésű motor esetén az $\varepsilon$ kompresszióviszonyt, a pneumatikus motorunk esetében pedig a sürített levegő kiszorítási térfogatát és expanzióját definiálja;

- amennyiben $\frac{r}{d}=n$, az epitrochoid egy lekerekített szabályos sokszöghöz hasonlít (nem azonos azzal, tehát nem lehet egyenesekböl és körívekből megszerkeszteni).

\subsection{A forgórész}

Míg az állórész körvonalát a bolygódugattyú élei generálták (egyes szakcikkek egy szabályos sokszög megforgatásával származtatják azt, ez az eljárás viszont nem 
alkalmazható általánosan), addig a forgórész legnagyobb kiterjedését abból a feltételből tudjuk meghatározni, hogy megszorulás nélkül körbe kell fordulnia az állórészben.

A szakirodalom a forgórész körvonalára nem ad meg általánosan használható egyenleteket. A Wankel-motor esetében a forgórészt néha Reuleaux-háromszög formájúnak tekintik, melyet úgy kapunk, hogy egy egyenlő oldalú háromszög csúcsaiból az oldalhosszal egyenlö sugarú köríveket húzunk. A dugattyú legnagyobb körvonalának egyenleteit talán meg lehetne állapítani, azonban a tervezés (CAD, CAM) és a kivitelezés (CNC) szempontjából előnyösebb a körvonalak koordináta-párokkal való leírása.
Ehhez egy újabb programot írtunk (4. ábra), amely első lépésben létrehozza az állórész körvonalait, majd a forgórész körbeforgatásával, mint egy burkológörbét, megállapítja annak körvonalát. Mindkét körvonal pontokból áll, amelyeket egy *.csv állományba lehet menteni, más programokkal való feldolgozás céljából.

Néhány, e programmal a Wankelmotorra kapott dugattyúkörvonalat a 3. táblázatban mutatunk be. Látható, hogy minél nagyobb a dugattyú sugara a gördülökörének sugarához viszonyítva (az $n^{\prime}$ hányados), annál kerekdedebb a dugattyú. A hányados egy adott értéke alatt a belső fogazású kerék gördülököre a burkológörbén kívül esik ezt a motort igen nehéz lenne megépíteni.

3. táblázat. Dugattyú-burkológörbék háromszögü dugattyú esetén

(n)


4. táblázat. Dugattyú-burkológörbék 2, 4, 5 és 10 szögü dugattyú esetén
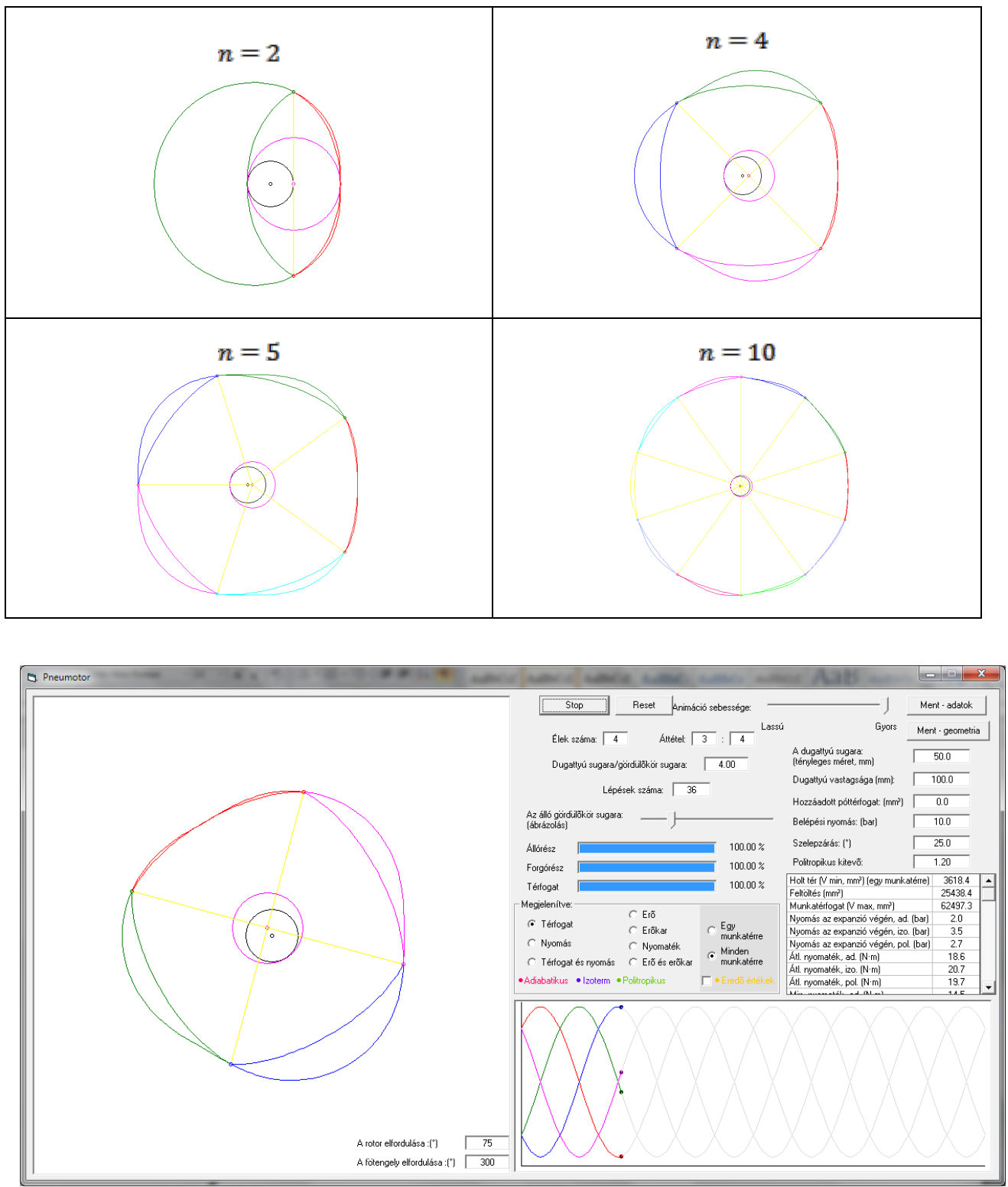

4. ábra. A program felhasználói felülete egy négyszögletü dugattyúval rendelkezö motor esete.

A 4. táblázat az élek más $n$ számára ad egy-egy példát.
A dugattyú valódi körvonala az így megszerkesztett burkológörbén belül kell legyen. A burkológörbét szabályos kör- 
ívekkel és egyenes szakaszokkal is megközelíthetjük (tehát az valóban lehet egy Reuleaux-sokszög vagy akár szabályos poligon), amennyiben az így megrajzolt profil a burkológörbe belsejében van.

A burkológörbénél kisebb dugattyúprofil használata a holttér növekedéséhez vezet. Amennyiben a pneumatikus motor expanzió nélküli, vagy pedig a gépünket kompresszorként akarjuk alkalmazni, ez a holttér egyszersmind káros teret is jelent, tehát ilyen esetekben nem ajánlott túlzott mértékben eltérni a burkológörbétől.

\section{Termodinamikai folyamatok}

A forgórész és a dugattyú közötti teret a dugattyú élei $n$ körbeforgó munkatérre osztják. Mialatt a dugattyú körbefordul, e munkaterek térfogata egy legkisebb $V_{\text {min }}$ és egy legnagyobb $V_{\max }$ között alternál. E munkatér az ideális profilok közötti térből és a hozzáadott póttérfogatból áll. A Wankelmotor esetében e térfogatváltozás teszi lehetővé a klasszikus Otto-ciklus négy ütemének a lejátszódását. A pneumatikus motorunk esetében csak két ütemünk van:

- növekedö térfogat mellett sürítettlevegö-bebocsátás, majd - ha expanziót is alkalmazunk-egy adott pillanattól a bebocsátószelep lezárásával expandáltatjuk azt;

- a térfogat csökkenése kezdetén a kibocsátószelepet megnyitjuk, azon keresztül távozik a levegő a következő ciklus kezdetéig.

E folyamatokat a következő 5. táblázat tartalmazza.

A levegő expanziója opcionális. Előnye az, hogy a munkavégző ütem végén alacsony nyomású, tehát alacsony energiájú levegő távozik a gépből, a sürített levegő nyomásából fakadó potenciális energia leg- nagyobb részét a motor munkává alakítja át, tehát gazdaságosabbá válik a müködtetés.

Az expandáltatás hátrányait a nyomaték erőteljes változása (amit valamennyire kompenzál az, hogy az $n$ munkatérben lejátszódó folyamatok részben fedik egymást) és a szelepek, vezérlés beépítésének szükségessége jelentik.

A munkatérben végbemenő folyamatok a fenti két ütemnek és két holtpontnak megfelelően a következők (5. ábra):

- $1 \rightarrow 2$ : A ,felső” holtpontban, szelepváltáskor hirtelen nyomásnövekedés, ami izochor folyamatnak tekinthetö, ez nyitott rendszerben megy végbe.

- $\quad 2 \rightarrow 3$ : A levegö bebocsátása izobár folyamat, ami nyitott rendszerben megy végbe.

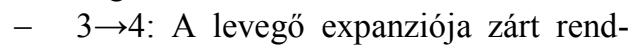
szerben megy végbe, ideálisan ez egy adiabatikus vagy pedig egy izoterm folyamat lenne. Valójában e folyamat a kettő között van. A pneumobilos tapasztalat azt mutatja, hogy azt politropikus folyamatként modellezhetjük (a munkahengerekkel megvalósított motor esetén a politropikus kitevő $\kappa=1.22$-nek adódott).

- A kibocsátószelep ,alsó” holtpontban való megnyitásakor ideálisan a munkatérfogatban levő nyomás az atmoszférikussal egyenlő. Ettől eltérő nyomás esetén izochor nyomásváltozást kell feltételeznünk, ami a hatásfok romlásához vezet (ha az expanzió túl jól sikerül és a nyomás az atmoszferikus alá csökken, az első ütem megfelelő szakaszán fékező hatás lép fel!).

- $\quad 4 \rightarrow 1$ : A második ütem alatt a térfogat csökken, ezalatt a kibocsátószelep nyitva áll. Ez egy nyitott rendszerben végbemenő izobár folyamat. 


\section{5. táblázat. A pneumatikus motor két üteme és két holtpontja}

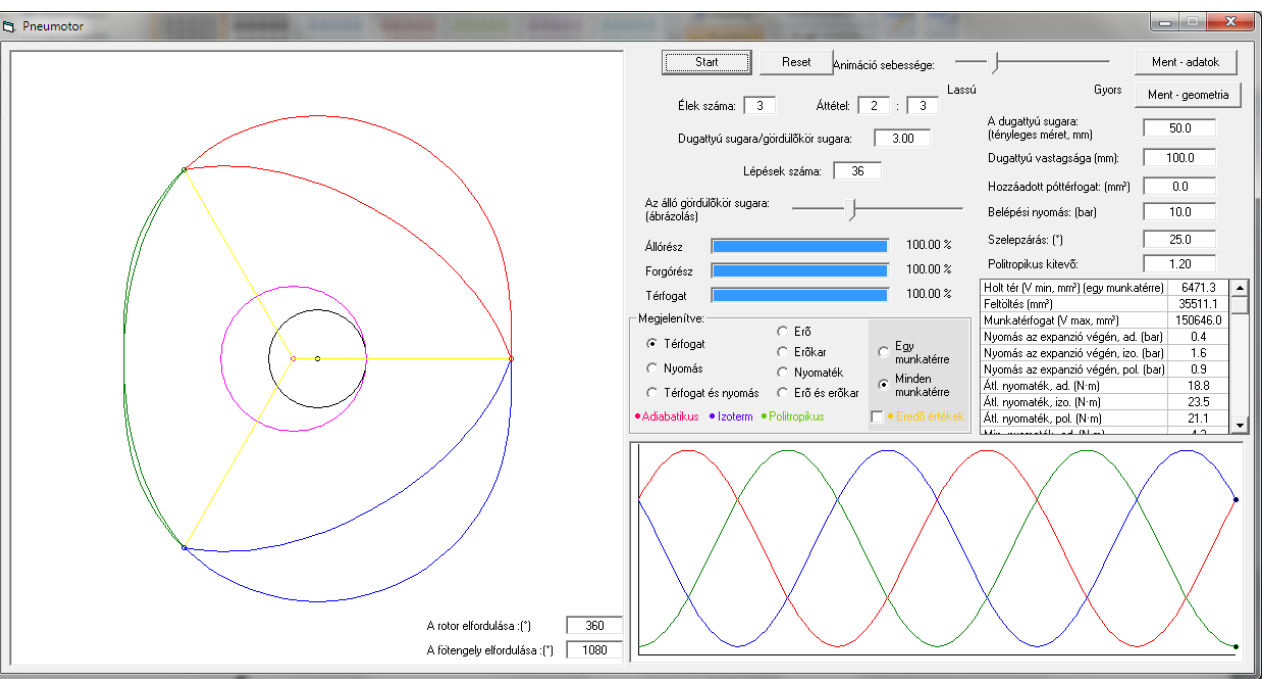

A zöld munkatér a legkisebb térfogatú, ez lenne a „felső holtpont”. Elkezdjük bebocsátani a sürített levegöt. Ezalatt a piros munkatér növekedik (itt a levegő expandál, munkavégzés történik), a kék pedig csökken (itt a levegő távozik).

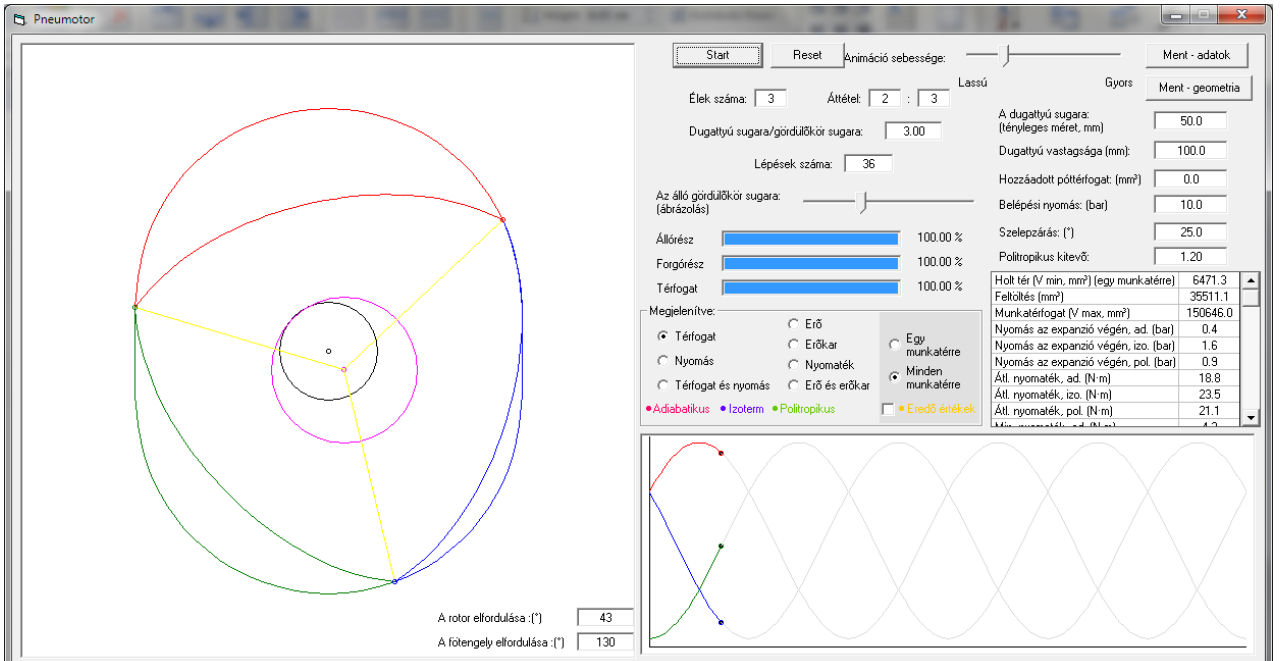

A zöld térfogat növekszik, ezalatt a bebocsátószelepet egy adott pillanatban lezárjuk, és attól kezdve itt a levegő nyomása az expanzió miatt csökkenni fog. Ez a munkavégző ütem, amely egy darabig párhuzamosan folyik a piros tér munkavégző ütemével. 
5. táblázat. A pneumatikus motor két üteme és két holtpontja (folyt.)

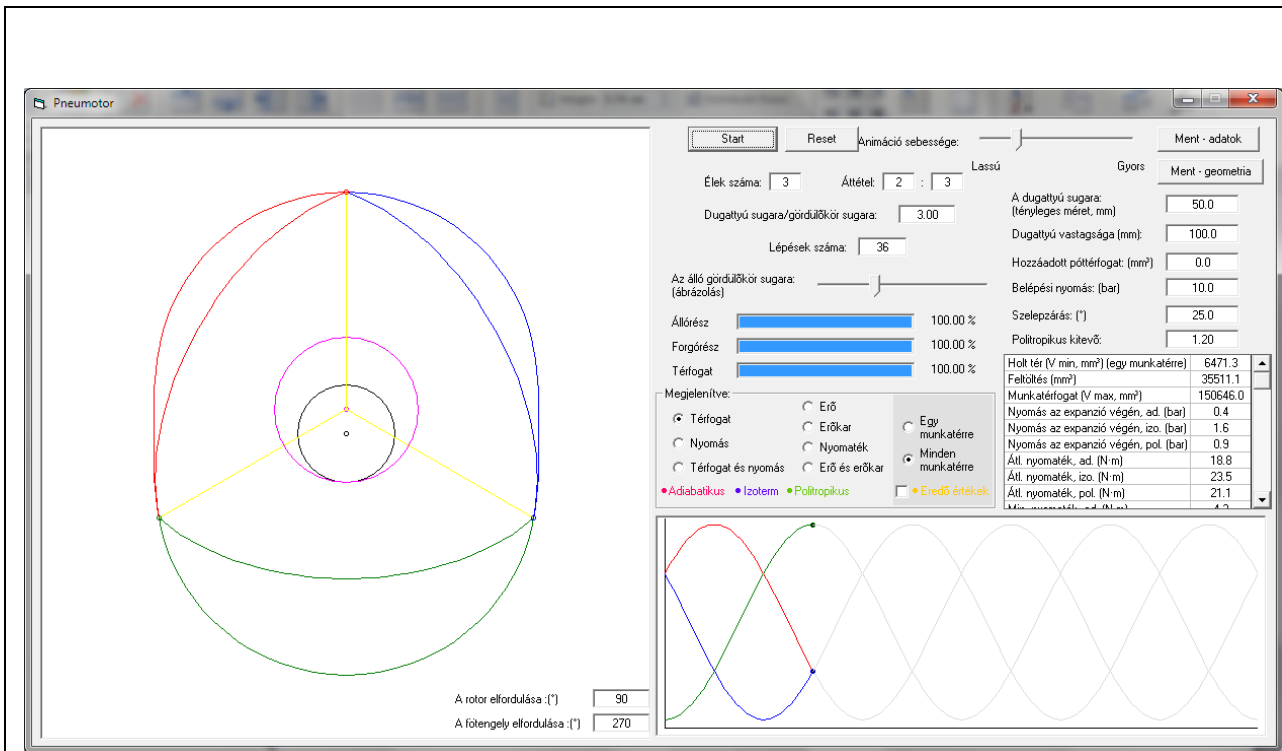

A zöld tér eléri a legnagyobb térfogatát, ez az „alsó” holtpont. Ekkorra az expandált levegő nyomása, ha takarékosan akarjuk üzemeltetni a gépünket, az atmoszferikus nyomás körül kell legyen. Ekkor nyílik meg a kibocsátószelep.

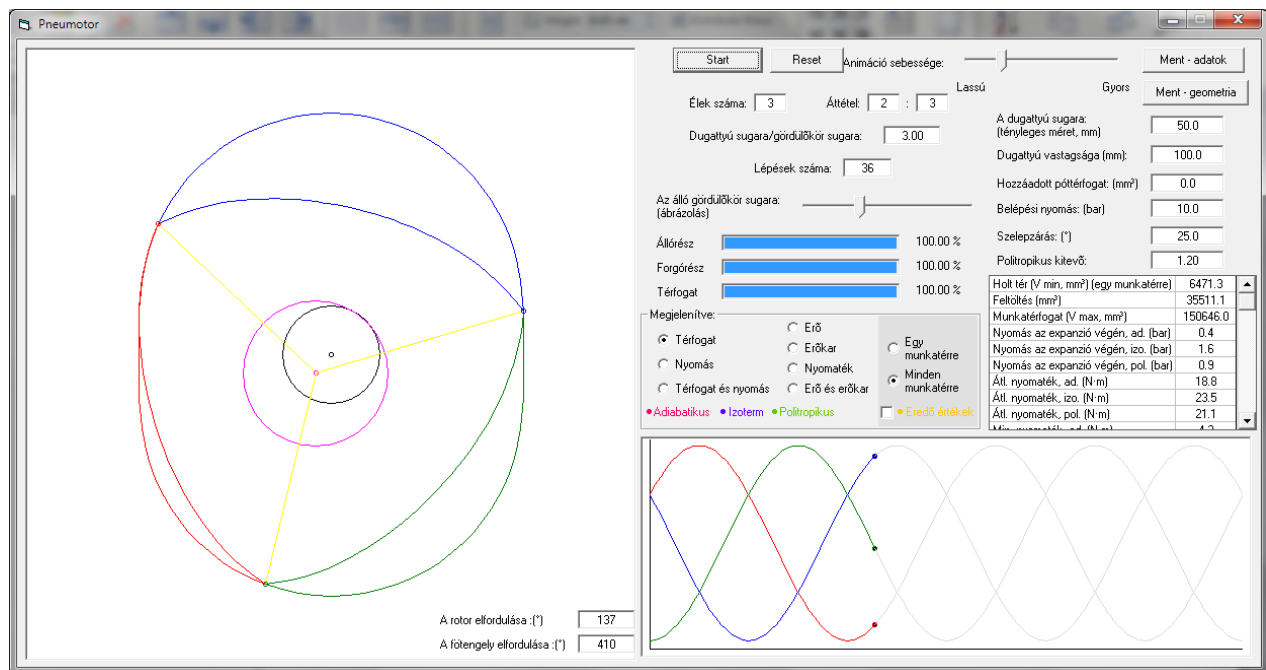

A zöld tér folyamatosan csökken, miközben a munkatérben maradt levegő távozik. Ez egészen addig tart, míg a térfogat el nem éri a legkisebb értékét, akkor szelepváltás történik, és a ciklus megismétlődik. 


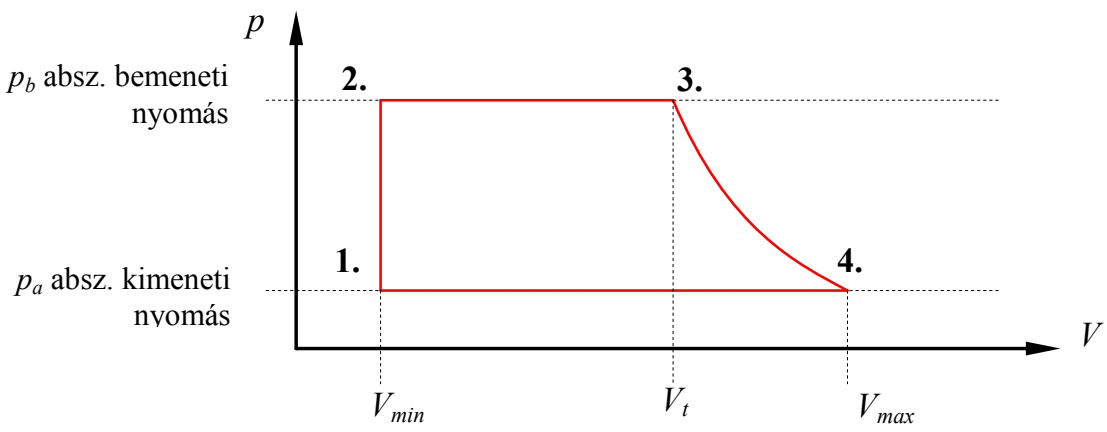

5. ábra. A motor termodinamikai ciklusa

E termodinamikai körfolyamat idealizált, azonban a pneumobilos tapasztalat azt mutatja, hogy a szenzorokkal kimért indikált diagram nem különbözik lényegesen az ábrázolt, ideális ciklustól. Éppen ezért nem követünk el nagy hibát, hogyha a motor által kifejtett nyomatékot, végzett munkát e diagram alapján számítjuk ki.

Az általunk megalkotott program a $3 \rightarrow 4$ expanzióra három lehetőséget ajánl fel, mindhárom esetet egy $p \cdot V^{\kappa}=$ áll. egyenlet ír le, ahol $p$ az abszolút nyomás. Izoterm expanzióra $\kappa=1$ (Boyle-Mariotte-gáztörvény), adiabatikus expanzióra $\kappa=1.44$ (Poisson-egyenlet, az adiabatikus kitevő ezen értéke kétatomos gázokra érvényes), politropikus expanzióra $\kappa \in(1,1.44)$; az értékét kísérletileg lehet megállapítani.

A program e folyamatokra külön-külön kiszámolja a nyomás változását, a dugattyúra ható hidrosztatikai erőt, az erőnek a motor forgattyújához viszonyított erőkarját és végül az erő nyomatékát.

\section{A motor vezérlése}

Az eredeti Wankel-motornak nincsenek szelepei, akárcsak egy kétütemű dugattyús motor esetében csak beömlő- és kiömlönyílásokkal találkozunk. Ez a megoldás azonban a pneumatikus motorunk esetében nem a legjobb, hiszen így nincs lehetőségünk a müködés optimális beállításaihoz. Ezek a beállítások dinamikusak kell legyenek. Mivel a pneumatikus rendszerekben a nyomásesés a hozam négyzetével együtt nő, a $p_{b e}$ bebocsátási nyomásunk igencsak terhelésfüggö lehet. Másrészt az expandáló levegő lehül, és ez a motor alkatrészeit is lehüti, így huzamosabb müködtetés után a $\kappa$ politropikus kitevő is érezhető módon megváltozhat.

A motorunkat tehát szelepekkel kell ellátnunk, a szelepeket pedig pl. egy PLC-vel kell vezérelnünk, a bemeneti nyomás, a hőmérséklet és a fordulatszám függvényében (ez utóbbi a szelepek késleltetését is figyelembe veheti, de készíthetünk szabályozott fordulatszámon müködő motort is).

A vezérlés legnagyobb problémája az $\mathbf{5}$. ábrán levő 3 -as pont kitüzése, amit a modellező programunkban a dugattyú elfordulási szögével adunk meg mint ,Szelepzárás"-t. A $V_{t}$ térfogat kiszámítása a

$$
p_{b} \cdot V_{t}^{\kappa}=p_{a} \cdot V_{\max }^{\kappa}
$$

egyenlet alapján történik, ahonnan

$$
V_{t}=\sqrt[\kappa]{\frac{p_{a}}{p_{b}}} \cdot V_{\text {max }}
$$


Az így kapott $V_{t}$ térfogattal meg kellene határozni a bebocsátószelep zárásának a „felső” holtponthoz viszonyított szögét. Mire erre analitikus képletünk egyelőre nincs, a szelepzárás szögét csak próbálkozással tudjuk beállítani.

\section{Következtetések: a motor mé- reteinek megválasztása}

A motor jellemző paraméterei a nyomaték és a teljesítmény. Ez utóbbit az egy fordulatra kiszámolt mechanikai munka és a fordulatszám szorzataként adhatjuk meg. Itt megjegyzendő, hogy a motor tengelyének a fordulatszáma nem azonos a dugattyú fordulatszámával, hanem annak $n$-szerese (tehát míg pl. a Wankel-motor dugattyúja bolygómozgása során a saját tengelye körül egyszer körbefordul, addig a fötengely három fordulatot tesz meg).

Az optimális geometria megválasztását parametrikus modellezéssel oldhatjuk meg. Azonos méretü és hasonló geometriájú (a 2. táblázat szerint) motorokra kapott eredmények alapján (a szelep időzítésével azonos expanzióvégi nyomásokat állítottunk be) elmondhatjuk, hogy:

- az élek számának növekedésével a motornak a dugattyú egy fordulatára eső munkatere és feltöltése jelentősen csökken;

- ha a munkateret a fötengely egy fordulatára számítjuk, akkor a csökkenés még erőteljesebb lesz (mivel az előbbi értéket az élek számával kell elosztanunk);

- a holttér aránya az élek számával növekedik (a hatásfok tehát romlik), míg a feltöltés aránya állandó;

- azonos méretek esetén a motor teljesítménye az élek számának növelése folytán tehát jelentős mértékben csökken;

- megvizsgáltuk, hogy termodinamikai szempontból mit jelent a dugattyú su- garának és a gördülökör sugarának aránya:

- az arány növekedésével az állórész belső körvonala egyre simább (ez majd a tömítés szempontjából lesz érdekes);

- az arány növekedésével a nyomaték egyre csökken, de

- csökken a holttér százalékos aránya is.

E következtetések alapján a közeljövőben tanulmányozandó prototípusunkat egy háromélü dugattyúval terveztük meg és kiviteleztük. A termodinamikai szempontból optimális gép a 4. táblázat bal felső részében szereplö, kétélü dugattyúval ellátott verzió lenne, azonban az egyenletes járáshoz ez valószínüleg két, egymáshoz viszonyítva $90^{\circ}$-kal elfordított dugattyúval kellene megépíteni.
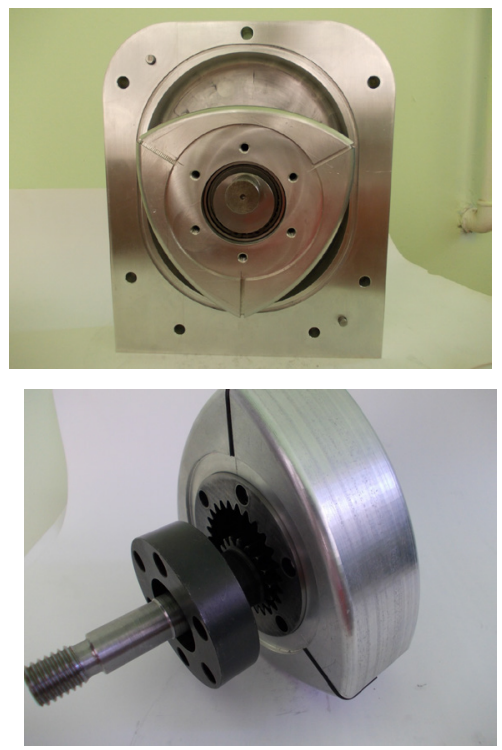

6. ábra. A prototípus föbb alkatrészei

A megépített prototípus egyik sajátossága az, hogy a dugattyú éleit és oldalait lekerekítettük a tömítések könnyebb kivitelezésének érdekében. E lekerekítések miatt nem lehet alkalmazni az eredeti Wankelmotor két fedőlappal lezárt állórészes meg- 
oldását, az most két, egymáshoz illeszkedő darabból áll (6. ábra).

\section{Szakirodalmi hivatkozások}

[1] Kenneth, C. Weston: Energy conversion. (7. fejezet: The Wankel Rotary Engine), Pws Pub Co 1992, ISBN-13: 978-0534938611, elektronikus formában:

www.personal.utulsa.edu/ kenneth-weston/

[2] Jan Norbye: The wankel engine: design, development, applications. (2. fejezet: Geometry) Chilton Book Co 1971, ISBN-13: 978-0801955914, elektronikus formában: https://netfiles.uiuc.edu/ro/www/SocietyforE xperimentalMechanics/wankelfiles/wankelge ometry.pdf?uniq=juflkq
[3] Papp István: $A 0$ / 00993 / 2010.10.20. iktatószámú szabadalom egy bolygódugattyús belsö égésü motorról.

[4] Az „Aratók” és a „Prérifarkas” pneumobilcsapatok tervdokumentációi (2008-2011)

A bolygódugattyús pneumatikus motor kutatását a Sapientia Alapítvány keretein belül múködő Kutatási Programok Intézete finanszírozta és tette lehetővé.

The development of the planetary-piston pneumatic engine was supported and financed by the Sapientia Foundation Institute for Scientific Research. 